\title{
KEBIJAKAN PENANGGULANGAN CYBER CRIME DAN CYBER SEX
}

\author{
Oleh : \\ Barda Nawawi Arief*
}

\begin{abstract}
ABSTRAK
Cyber crime di bidang kesusilaan, yang berupa cyber pornography dan cyber sex dapat menjadi masalah yang serius apabila tidak diantisipasi melalui kebijakan hukum pidana. Kebijakan umum yang pertu diterapkan adalah dengan pendekatan integral/sistemik yang memadukan pendekatan teknologi, pendekatan budayal kultural, pendekatan moralledukatif dan pendekatan global. Kebijakan penanggulangan cyber pornography dapat ditemukan dalam KUHP dan juga dalam UU No. $32 / 2002$ tentang Penyiaran, meskipun terdapat kelemahan dalam asas teritorial. Untuk mengantisipasi hal tersebut dalam Konsep RUU KUHP 2004/2005, dirumuskan perluasan asas teritorial dan perumusan delik Pornografi Anak melalui Komputer Sedangkan cyber sex sulit dijangkau oleh hukum pidana positif saat ini, karena perbuatannya bersifat maya/abstrak non-fisik dan sangat individual serta selalu bertolak dari paradigma perbuatan dalam arti fisik/materiel. Oleh karena itu dalam praktek peradilan, hakim dapat melakukan konstruksi hukum dengan menyatakan bahwa cybersex atau "hubungan seksual non-fisik (maya)" ini merupakan bentuk zina dalam pengertian Pasal 284 KUHP. Hal itu didasarkan pada alasan juridis normatif, juridis konseptuallteoritik/keilmuan, jurisprudensi, pandangan pakar, agama, dan dari sudut akibat sosial (dampak negatifnya
\end{abstract}

Kata Kunci Kebijakan Hukum Pidana, Cyber Crime, Cyber Pornography, Cyber Sex.

A. CYBER CRIME-CYBER SEX:

SISI GELAP DARI

TEKNOLOGI MAJU

Kehidupan dunia modern saat ini tidak dapat dilepaskan, dan bahkan sangat sering bergantung pada kemajuan teknologi canggih/ maju ("hitech" atau "advanced

\footnotetext{
${ }^{*}$ Prof.Dr.Barda Nawawi Arief, SH Adalah Guru Besar Hukum Pidana di Fakultas Hukum UNDIP dan Ketua Program Magister limu Hukum UNDIP
}

technology') di bidang informasi dan elektronik melalui jaringan internasional (internet).

Di satu sisi, kemajuan teknologi canggih itu membawa dampak positif di berbagai kehidupan, seperti adanya e-mail, e-commerce, e-learning, "EFTS" (Electronic Funds Transfer System) 
atau "sistem transfer dana elektronik"), "Internet Banking", "Cyber Bank", "On-line Business" dsb. Namun di sisi lain, juga membawa dampak negatif, yaitu dengan munculnya berbagai jenis "hitech crime" dan "cyber crime", sehingga dinyatakan bahwa "cyber crime is the most recent type of crime" ${ }^{8}$ dan "cyber crime is part of the seamy side of the Information Society" (CC merupakan bagian sisi paling buruk dari Masyarakat Informasi ' $^{9}$.

Semakin berkembangnya cyber crime terlihat pula dari munculnya berbagai istilah seperti economic cyber crime, EFT (Electronic Funds Transfer) Crime, Cybank Crime, Internet Banking Crime, On-Line Business Crime, Cyberl Electronic Money Laundering, Hitech WWC (white collar crime), Internet fraud (antara lain Bank fraud, Credit card fraud, On-line fraud), cyber terrorism, cyber stalking, cyber sex, cyber pornography, cyber defamation, cyber-criminals, $d s b$.

Dengan semakin berkembangnya cyber crime, sangatlah wajar masalah ini sering dibahas di berbagai forum nasional dan internasional. Kongres PBB mengenai "The Prevention of Crime and the Treatment

\footnotetext{
${ }^{8}$ V.D. Dudeja, Cyber Crimes and Law, Volume 2, 2002, p. v.

Data Protection Working Party, Council of Europe, "Opinion 4/2001 On the Council of Europe's Draft Convention on Cyber-crime", adopted on 22 March 2001, 5001/01/EN/Final WP 41, p. 2
}

of Offenders ${ }^{10}$ (yang diselenggarakan tiap 5 tahun) telah pula membahas masalah ini sampai tiga kali, yaitu pada Kongres VIII/1990 di Havana, Kongres $X / 2000$ di Wina, dan terakhir pada Kongres XI/2005 di Bangkok (tanggal 18-25 April yang lalu). Dalam "background paper" lokakarya "Measures to Combat Computer-related Crime" Kongres XI PBB dinyatakan, bahwa "tekno-logi baru yang mendunia di bidang komunikasi dan informasi memberikan "bayangan gelap" (a dark shadow) karena memungkinkan terjadinya bentuk-bentuk eksploitasi baru, kesempatan baru untuk aktivitas kejahatan, dan bahkan bentuk-bentuk baru dari kejahatan".

Salah satu masalah cyber crime yang juga sangat meresahkan dan mendapat perhatian berbagai kalangan, adalah masalah cyber crime di bidang kesusilaan. Jenis cyber crime di bidang kesusilaan yang sering diungkapkan adalah cyber pornography (khususnya child pornography) dan cyber sex.

\footnotetext{
${ }^{10}$ Dalam Kongres $\mathrm{XI}$, judul kongres berubah menjadi Congress on Crime Prevention and Criminal Justice.

Dokumen United Nations A/CONF.203/14 Eleventh United Nations Congress on Crime Prevention and Criminal Justice, Bangkok, 1825 April 2005, Background paper, Workshop 6: Measures to Combat Computer-related Crime : "The worldwide multiplication of new information and communication technologies also casts a dark shadow: it has made possible new forms of exploitation, new opportunities for criminal activity and indeed new forms of crime".
} 


\section{B. CYBER CRIME DI BIDANG KESUSILAAN}

1. Pengertian dan Ruang Lingkup Tindak Pidana Kesusilaan

Secara singkat dapat dikatakan, bahwa delik kesusilaan adalah delik yang berhubungan dengan (masalah) kesusilaan. Namun tidaklah mudah menetapkan batas-batas atau ruang lingkup delik kesusilaan, karena pengertian dan batas-batas "kesusilaan" itu cukup luas dan dapat berbeda-beda menurut pandangan dan nilai-nilai, yang berlaku di dalam masyarakat. Terlebih karena hukum itu sendiri pada hakikatnya merupakan nilai-nilai kesusilaan yang minimal (das Recht ist das ethische Minimum $)^{12}$, sehingga pada dasarnya setiap delik atau tindak pidana merupakan delik kesusilaan.

Secara juridis, delik kesusilaan menurut KUHP yang berlaku saat ini terdiri dari 2 (dua) kelompok tindak pidana, yaitu "kejahatan kesusilaan" (diatur dalam Bab XIV Buku II) dan "pelanggaran kesusilaan" (diatur dalam Bab VI Buku III).

\footnotetext{
Ungkapan serupa, dikemukakan oleh George Jellinek bahwa "the law as an ethical minimum" (Stephen Schafer, The Political Criminal, 1973, p. 67)); juga terlihat dalam ungkapan Alfred Denning, bahwa "without religion there can be no morality, and without morality there can be no law (Oemar Senoadji, "Mass Media dan Hukum", 1977. hal. 141).
}

Yang termasuk kelompok "kejahatan kesusilaan" (Pasal 281 - 303 KUHP) meliputi perbuatan perbuatan :

a. melanggar kesusilaan di muka umum (Pasal 281);

b. menyiarkan, mempertunjukkan, membuat, menawarkan dsb. tulisan, gambar, benda yang melanggar kesusilaan/bersifat porno (Psl. 282-283);

c. melakukan zina, perkosaan dan hal-hal lain yang berhubungan dengan melakukan atau menghubungkan/memudahkan perbuatan cabul dan hubungan seksual (Pasal 284296);

d. perdagangan wanita dan anak laki-laki di bawah umur (Pasal 297);

e. yang berhubungan dengan pengobatan untuk menggugurkan kehamilan (Pasal 299);

f. yang berhubungan dengan minuman memabukkan (Pasal 300);

g. menyerahkan anak untuk pengemisan dan sebagainya (Pasal 301);

h. penganiayaan hewan (Pasal 302);

i. perjudian (Pasal 303 dan 303 bis);

Adapun yang termasuk "pelanggaran kesusilaan" menurut KUHP (Pasal 532-547) meliputi perbuatanperbuatan : 
a. mengungkapkan/mempertunjukkan sesuatu yang bersifat porno (Pasal 532-535);

b. yang berhubungan dengan mabuk dan minuman keras (Pasal 536-539);

c. yang berhubungan dengan perlakuan tidak susila terhadap hewan (Pasal 540, 541 dan 544);

d. meramal nasib/mimpi (Pasal 545);

e. menjual dan sebagainya jimat-jimat, benda berkekuatan gaib atau memberi pelajaran ilmu kesaktian (Pasal 546);

f. memakai jimat sebagai saksi di persidangan (Pasal 547);

Telah dikemukakan di atas, bahwa orang bisa berbeda pendapat mengenai batasan pengertian dan ruang lingkup delik kesusilaan. Prof. Mr. Roeslan Saleh misalnya pernah mengemukakan, bahwa pengertian kesusilaan hendaknya tidak dibatasi pada pengertian kesusilaan dalam bidang seksual, tetapi juga meliputi hal-hal lain yang termasuk dalam norma-norma kepatutan bertingkah laku dalam pergaulan masyarakat. Oleh karena itu beliau menyarankan, agar tindak pidana berupa "meninggalkan orang yang perlu ditolong", "penghinaan", dan "membuka rahasia" juga dimasukkan ke dalam "tindak pidana terha- dap kesusilaan" ${ }^{13}$ (Catatan : ketiga kelompok jenis tindak pidana ini, dalam KUHP diatur dalam bab-bab tersendiri).

Dalam berbagai KUHP Asing, pengelompokan delik kesusilaan juga berbeda-beda dan tampaknya bergantung pada kesepakatan dan kebijakan pembuat undang-undang. ${ }^{14}$ Walaupun pengelompokan atau ruang lingkup delik kesusilaan bisa berbeda-beda, namun patut dicatat pendapat Prof. Mr. Roeslan Saleh yang menggarisbawahi pandangan Prof. Oemar Senoadji, bahwa dalam menentukan isinya (materi/substansi) harus bersumber dan mendapat sandaran kuat dari moral agama (lihat makalah dalam Lokakarya yang disebut di atas).

Saya akan menggarisbawahi pandangan yang demikian walaupun patut ditambahkan, bahwa penentuan delik kesusilaan juga harus berorientasi pada "nilai-nilai kesusilaan nasional" (NKN) yang telah disepakati bersama dan juga memperhatikan nilai-nilai kesusilaan yang hidup di dalam masyarakat. NKN ini dapat digali antara lain dari produk legislatif nasional (berbentuk Undang-undang Dasar atau undang-

\footnotetext{
13 Lihat makalah Roeslan Saleh, dalam lokakarya "Bab-bab Kodifikasi Hukum Pidana (Buku II)", diselenggarakan oleh BPHN Departemen Kehakiman, tanggal 23 - 25 April 1985 di Jakarta.

Lihat Lampiran (Tabel); lihat juga Barda Nawawi Arief, "Bunga Rampai Kebijakan Hukum Pidana", 1996, Bab XIII; dan "Sari Kuliah Perbandingan Hukum Pidand", 2002, Bab XV.
} 
undang). Dalam struktur masyarakat Indonesia, NKN itupun tentunya bersumber dari nilai-nilai agama dan kesusilaan yang hidup di tengahtengah masyarakat.

2. Jenis dan Frekuensi Cyber Crime Di Bidang Kesusilaan

Berbagai delik kesusilaan yang dikemukakan di atas, dapat juga terjadi di ruang maya (cyber space), terutama yang berkaitan dengan masalah pornografi, mucikari/ calo, dan pelanggaran kesusilaan/ percabulan/perbuatan tidak senonoh/ zina. Semakin. maraknya pelanggaran kesusilaan di dunia cyber ini, terlihat dengan munculnya berbagai istilah seperti : cyber porno-graphy (khususnya child pornography), online pornography, cyber sex, cyber sexer, cyber lover, cyber romance, cyber affair, on-line romance, sex on-line, cybersex addicts, cyber sex offender.

Dunia maya (cyber/virtual world) atau internet dan World Wide Web (www) saat ini sudah sangat penuh (berlimpah) dengan bahan-bahan pornografi atau yang berkaitan dengan masalah seksual. Menurut perkiraan, $40 \%$ dari berbagai situs di www menyediakan bahan-bahan seperti itu ${ }^{15}$. Bahkan dinyatakan dalam tesis Peter David Goldberg,

15 Lihat Gloria G. Brame, "Boot Up and Turn Orr; 1996, gloria-brame.com/glory/joum7.htm yang bersumber dari Nua Internet Surveys 2001, bahwa sex merupakan topik paling populer di internet (the most popular topic on the internet ${ }^{16}$. Pernyataan ini mirip dengan yang ditulis Mark Griffiths (bersumber dari Freeman-Longo \& Blanchard, 1998) ${ }^{17}$, bahwa sex merupakan topik yang paling banyak dicari di internet ("sex is the most frequently searched-for topic on the Internet"). Dalam tesis Goldberg dikemukakan pula, bahwa perdagangan bahan-bahan porno melalui internet sudah mencapai milyaran dollar US per tahun; sekitar $25 \%$ pengguna internet mengunjungi lebih dari 60.000 situs sex tiap bulan, dan sekitar 30 juta orang memasuki situs sex tiap hari.

Gambaran singkat di atas tentunya cukup meresahkan/memprihatinkan, karena tidak mustahil bisa juga terjadi di Indonesia. Beredarnya foto hubungan seksual seorang siswi di Sampit. beberapa waktu yang lalu, yang direkam dengan kamera digital dan disebarkan melalui MMS (multy media message), merupakan salah satu contoh penyalahgunaan teknologi

\footnotetext{
16 Peter David Goldberg, An Exploratory Study About the Impacts that Cybarsax The Use of the Internot for Sexud Puposes) is Having on Families and The Practices of Marriage and Fomily Therapists, 2004, ${ }_{17}$ (pedrogoldberg@aol.com) Mark Griffiths, Sex on the intemot: obsovetions and implications for Internet sex addiction, Joumal of Sex Research, Nov, 2001, mark.griffiths@ntu.ac.uk.

18 Peter David Goldberg, op. cit.
} 
maju. Hal ini tentunya sangat meresahkan, karena kemajuan teknologi ternyata tidak digunakan sebagai sarana positif untuk meningkatkan kualitas kehidupan, tetapi justru digunakan sebagai sarana negatif yang dapat membawa dam-pak negatif. Keprihatinan terhadap dampak negatif dari teknologi maju ini, pernah diungkapkan pula oleh Art Bowker, seorang ahli Computer crime dari Amerika. la menyatakan antara lain, bahwa teknologi maju telah meningkat menjadi "way of life" masyarakat kita, namun sangat disayangkan, teknologi maju ini menjadi alat/sarana pilihan bagi para pelaku cybersex ("cybersex offen$\left(d e r^{2}\right)^{19}$.

\section{Cybersex dan Akibat-akibatnya}

\section{a) Pengertian Cybersex}

Menurut Peter David Goldberg, cybersex adalah "penggunaan internet untuk tujuan-tujuan seksual" ("the use of the Internet for sexual purposes $^{\prime 20}$. Senada dengan ini, Dr.

\footnotetext{
19 Art Bowker and Michael Gray, $A n$ Introduction to the Supervision of the Cybersex Offender, www.uscourts.gov Publishing Information: Advanced Technologies are increasingly becoming a way of life for our society. Computers are found in every home, school, and business, with more and more individuals: going "online" every day. Unfortunately, these advanced technologies (computers, scanners, digital cameras, the Internet, etc.) are becoming the tool of ${ }_{20}$ choice for the "cybersex offender."

2o Peter David Goldberg, op. cit., pedrogoldberg@aol.com
}

David Greenfield mengemukakan, bahwa cybersex adalah "menggunakan komputer untuk setiap bentuk ekspresi atau kepuasan seksual" ("using the computer for any form of sexual expression or gratifycation". Dikemukakan juga olehnya, bahwa cybersex dapat dipandang sebagai "kepuasan/kegembiraan maya" ("virtual gratification"), dan suatu "bentuk baru dari keintiman" ("a new type of intimacy" $)^{21}$. Patut dicatat, bahwa hubungan intim atau keintiman ("intimacy") itu dapat juga mengandung arti "hubungan seksual atau perzinahan" ${ }^{22}$. Ini berarti, cybersex merupakan bentuk baru dari perzinahan.

Dalam ensiklopedia bebas Wikipedia dinyatakan, bahwa "Cybersex" atau "computersex" adalah "pertemuan sex secara virtual/maya antara dua orang atau lebih yang terhubung melalui jaringan internet dengan mengirimkan pesan-pesan seksual yang menggambarkan suatu pengalaman seksual". Cybersex computersex merupakan bentuk permainan-peran (role-playing) antara para partisipan yang berpura-pura atau menganggap dirinya melakukan hubungan seksual secara nyata, dengan menggambarkan sesuatu untuk mendorong perasaan/fantasi

\footnotetext{
21 Dalam Gloria G. Brame, op. cit., gloriabrame.com/glory/journ7.htm

Lihat John M. Echols dan Hassan Shadily, Kamus Inggris Indonesia, 2000, halaman 328. Dalam kamus Hornby, 1963, halaman 517, disebut dengan istilah "illicit sexual relations".
} 
seksual mereka. Cybersex ini terkadang disebut juga dengan istilah "cybering" ${ }^{23}$. Menurut Greenfield dan Orzack, cybering ini dimasukkan dalam penggolongan cybersex yang berupa Online Sexual Activity (OSA) karena dengan cybering itu, salah seorang atau kedua orang yang saling berfantasi itu dapat melakukan masturbasi (onani) $^{24}$. Bahkan menurut Kenneth Allen, "An important and major element of cybersexual activity is masturbation ${ }^{25}$.

Pengertian "Cybering" atau "sex on the Internet" dikemukakan pula oleh Michael G. Conner, Psy.D sebagai "diskusi seksual secara "online" dengan tujuan mencapai orgasme (puncak syahwat) ${ }^{26}$.

\footnotetext{
23 Wikipedia, the free encyclopedia, (en.wikipedia.org/ wiki/Cybersex): "Cybersex or computer sex is a virtual sex encounter in which two or more persons connected remotely via a computer network send one another sexually explicit messages describing a sexual experience, by describing their actions and responding to their chat partners in a mostly written form designed to stimulate their own sexual foelings and fantasies. ..........t is a form of role-playing in which the participants pretend they are having actual sexual intercourse, ..... Cybersex is sometimes colloquially called "cybering".

24 Lihat dalam Peter D. Goldberg, op. cit. ; Greenfield dan Orzack mendefinisikan "cybering" sebagai "direct use by two people who share the same fantesy while one or both masturbate".

25 Kenneth Allen, Cyber-Sex A Roviow and Implications of the Situation,

(nome.earthlink.net).

Michael G. Conner, Psy.D, Intemet Addiction \& Cyber Sex, (www.CrisisCounseling.org) : "Cybering", or sex on the Internet, is defined as the consensual sexual discussion on-lino for the purpose of achieving arousal or an orgasm.
}

b) Akibat/Dampak Negatif Cybersex

Meningkatnya cybersex mengundang minat orang untuk melakukan berbagai penelitian. Penelitian yang telah dilakukan di Amerika, antara lain : (1) Cooper dkk., 2000, meneliti tentang "ciri-ciri dan pola kebiasaan para pecandu cybersex (cybersex addicts)"; (2) Schneider, 2000, meneliti tentang "pengaruh/akibat penggunaan cybersex terhadap pasangan mereka sendiri (suami/istri)"; dan (3) Peter David Goldberg, 2004, meneliti tentang "pengalaman para terapis keluarga dan perkawinan terhadap klien yang mengalami konflik akibat penggunaan cybersex".

Berdasarkan penelitian tersebut, banyak dijumpai akibat-akibat negatif dari penggunaan cybersex terhadap diri sipelaku maupun terhadap hubungan perkawinan, terhadap keseluruhan hubungan/sistem kekeluargaan, dan terhadap anak-anak mereka. Akibat terhadap diri pelaku, antara lain, merubah pola tidur, mengisolasi diri dari keluarga, mengabaikan tanggung jawab, berdusta, berubahnya kepribadian, kehilangan daya tarik terhadap partnernya (istri/suaminya), bersifat ambigius/ mendua, timbul perasaan malu dan bersalah, hilangnya rangsangan nafsu dan adanya gangguan ereksi 
(erectile dysfunction). Akibat terhadap partnernya (istri/suami) dan anak-anak, antara lain : timbul perasaan dikhianati, dilukai, dikesampingkan, dihancurkan, ditelantarkan, kesepian, malu, cemburu, kehilangan harga diri, perasaan dihina, anakanak merasa kehilangan perhatian orang tua, depresi (karena pertengkaran orang tua).

Adanya akibat-akibat demikian, maka sering timbul pertengkaran keluarga yang berakibat pada perceraian. Menurut Carl Salisbury (pengacara di Hanover, New York), gugatan perkara yang berkaitan dengan cybersex menunjukkan peningkatan di pengadilan-pengadilan Amerika. Dikatakan pula olehnya: "Tidak dapat dihindari bahwa kita sedang menyaksikan semakin banyaknya kasus-kasus perceraian yang disebabkan oleh cybersex ${ }^{28}$.

Cukup banyaknya akibat negatif dari cyber crime di bidang kesusilaan dan berbagai bidang lainnya, tentunya memerlukan kajian serius terhadap kebijakan penanggulangannya.

\footnotetext{
27 Lihat antara lain Peter David Goldberg, op. cit., disebutnya dengan istilah "feelings of betrayal, hurt, rejection, devastation, abandonment, loneliness, shame, jealousy, loss of self-esteem, humiliation"; isolate themselves from their partners or parents; ${ }_{28}$ affect the family's sense of mutuality;

28 Gloria G. Brame, op. cit.
}

\section{C.KEBIJAKAN HUKUM PIDANA (PENAL POLICY DALAM PE- NANGGULANGAN CYBER CRIME DI BIDANG KESUSILAAN}

\section{Kebijakan Umum}

Dilihat dari sudut "criminal policy", upaya penanggulangan kejahatan (termasuk penanggulangan $\mathrm{Cy}$ ber crime) tentunya tidak dapat dilakukan secara parsial dengan hukum pidana (sarana "penal"), tetapi harus ditempuh pula dengan pendekatan integral/sistemik. Sebagai salah satu bentuk dari "hitech crime" ${ }^{29}$, adalah wajar upaya penanggulangan cyber crime (disingkat $\mathrm{CC}$ ) juga harus ditempuh dengan pendekatan teknologi (techno prevention). Di samping itu diperlukan pula pendekatan budaya/ kultural, pendekatan moraledukatif (terlebih untuk delik kesusilaan), dan bahkan pendekatan global (kerja sama internasional) karena CC dapat melampaui batas-batas negara (bersifat transnational/ transborder) ${ }^{30}$.

\footnotetext{
29 Australian High Tech Crime Centre 2003 membagi "Hitech crime" secara kasar dalam dua kategori : (1) crimes committed with or against computers or communication systems, (2) traditional crimes which are largely facilitated by technology.

${ }^{30}$ Lihat antara lain Eighth UN Congress on the Prevention of Crime and the Treatment of Offenders, Report, 1991, hal. 141 dst. dan ITAC, "IIIC Common Views Paper On: Cyber Crime", IIIC 2000 Millenium Congress, September $19^{\text {th }}, 2000$, p. 5, dalam Barda Nawawi Arief, Sari Kuliah Perbandingan Hukum Pidana, PT RajaGrafindo, Jakarta, 2002, hal. 253 - 256.
} 
2. Kebijakan Penanggulangan (Penegakan Hukum) Dengan Hukum Pidana Positif

\section{a. Terhadap Cyber (child) Por- nography}

Dilihat dari substansinya, Cyber pornography dan cyber . child pornography jelas sudah tercakup dalam perumusan delik kesusilaan dalam KUHP, karena delik pornografi dalam KUHP meliputi antara lain:

1. Dalam Pasal 282 :

- menyiarkan, mempertunjukkan atau menempelkan di muka umum tulisan, gambaran atau benda yang melanggar kesusilaan,

- membikin tulisan, gambaran atau benda tersebut (dengan maksud untuk disiarkan, dipertunjukkan atau ditempelkan di muka umum),

- memasukkannya ke dalam negeri, meneruskannya, mengeluarkannya dari negeri, atau mempunyainya dalam persediaan (dengan maksud untuk disiarkan, dipertunjukkan atau ditempelkan di muka umum); atau

- menawarkannya atau menunjukkannya sebagai bisa diperoleh (tanpa unsur di muka umum);
2. Dalam Pasal 283

- Menawarkan, memberikan, menyerahkan atau memperlihatkan tulisan, gambaran atau benda yang melanggar kesusilaan kepada seorang yang belum cukup umur, dan yang diketahui atau sepatutnya harus diduga bahwa umurnya belum tujuh belas tahun;

3. Dalam Pasal 533 :

- di tempat lalu lintas umum, mempertunjukan atau menempelkan tulisan gambar atau benda, yang mampu membangkitkan/merangsang nafsu birahi para remaja;

- menawarkan maupun menunjuk sebagai bisa didapat tulisan, gambar atau barang yang dapat merangsang nafsu birahi para remaja (tanpa unsur di tempat umum);

- menawarkan, memberikan, menyerahkan atau memperlihatkan gambar atau benda yang demikian (yang dapat membangkitkan nafsu birahi), pada seorang yang belum cukup umur dan dibawah umur tujuh belas tahun (tanpa unsur di tempat umum);

Namun kelemahan dari ketentuan KUHP di atas ialah, hanya dapat diterapkan terhadap delik yang 
dilakukan di dalam wilayah teritorial Indonesia. Delik yang di-lakukan oleh orang asing di luar wilayah teritorial Indonesia, tidak dapat dijangkau oleh KUHP.

Di samping KUHP, cyber (child) pornography sebenarnya juga dapat dijaring dengan UU No. 32/2002 (Penyiaran), karena dalam UU ini terdapat ketentuan sebagai berikut :

1. Psl. 57 jo. 36 (5) mengancam pidana terhadap SIARAN yang (antara lain) menonjolkan unsur cabul.

2. Psl. 57 jo. 36 (6) mengancam pidana terhadap SIARAN yang memperolokkan, merendahkan, melecehkan dan/atau mengabaikan nilainilai agama, martabat manusia Indonesia.

3. Psil. 58 jo. 46 (3) mengancam pidana terhadap SIARAN IKLAN NIAGA yang di dalamnya memuat (antara lain):

a. hal-hal yang bertentangan dengan kesusilaan masyarakat dan nilai-nilai agama, dan/atau

b. eksploitasi anak di bawah umur 18 tahun.

Ketentuan di atas dapat ditujukan kepada cyber crime di bidang kesusilaan, karena menurut UU tersebut, yang dimaksud dengan : a. "Penyiaran" adalah kegiatan pemancarluasan siaran melalui sarana pemancaran dan/atau sarana transmisi di darat, di laut atau di antariksa dengan menggunakan spektrum frekuensi radio melalui udara, kabel, dan/atau media lainnya untuk dapat diterima secara serentak dan bersamaan oleh masyarakat dengan perangkat penerima siaran (Pasal 1 ke-1);

b. "Siaran" adalah pesan atau rangkaian pesan dalam bentuk suara, gambar, atau suara dan gambar atau yang berbentuk grafis, karakter, baik yang bersifat interaktif maupun tidak, yang dapat diterima melalui perangkat penerima siaran (Pasal $1 \mathrm{ke}-1)$; dan

c. "Siaran iklan niaga" adalah siaran iklan komersial yang disiarkan melalui penyiaran radio atau televisi dengan tujuan memperkenalkan, memasyarakatkan, dan/atau mempromosikan barang atau jasa kepada khalayak sasaran untuk mempengaruhi konsumen agar menggunakan produk yang ditawarkan (Psl. 1 ke-6).

Walaupun UU No. $32 / 2002$ di atas dapat digunakan untuk menjaring cyber crime di bidang kesusilaan yang berkaitan dengan delikdelik penyiaran, namun kelemahan 
jurisdiksi teritorial dalam KUHP sebagaimana dikemukakan $\mathrm{di}$ atas juga berlaku untuk UU ini. Di samping itu, kelemahan lainnya ialah : tidak adanya penentuan kualifikasi delik (sebagai kejahatan atau pelangga-ran), dan tidak adanya ketentuan tentang pertanggungjawaban pidana korporasi, padahal delik-delik penyiaran dan iklan sangat terkait erat dengan korporasi. Menurut Pasal 14 dan 16 UU No. 32/2002, lembaga penyiaran berbentuk badan hukum.

\section{b. Terhadap Cybersex}

Berdasarkan pengertian cybersex yang telah dikemukakan di atas, dapat diidentifikasikan adanya pendapat, bahwa cybersex computersex :

1. adalah "penggunaan internet untuk tujuan-tujuan seksual";

2. adalah "penggunaan komputer untuk setiap bentuk ekspresi atau kepuasan seksual"

3. merupakan "bentuk baru dari keintiman" ("a new type of intimacy"), yang dapat juga diartikan sebagai "bentuk baru dari perzinahan atau hubungan seksual yang gelap/haram/ melanggar hukum" ("illicit sexual relations);

4. dapat dipandang sebagai bentuk "ekspresi atau kepuasan seksual maya" ("virtual sex expression/gratifycation)

5. merupakan bentuk "pertemuan sex secara virtual/ maya" (virtual sex en-counter) atau "sex on-line";

6. pertemuan dua orang atau lebih yang terhubung melalui jaringan internet dengan mengirimkan pesan-pesan seksual atau menggambarkan pengalaman seksual untuk mem bangkitkan rangsangan/ perasaan/fantasi seksual, sehingga terjadi masturbasi (onani);

7. dilihat dari sudut akibat, banyak dampak negatif bagi sipelaku sendiri, meretakkan/ merusak/ menghancurkan harmonisasi hubungan perkawinan, merusak sistem kekeluargaan, dan merusak/membahayakan anak-anak.

Mengamati hal-hal di atas, nampaknya cyber sex sulit dijangkau oleh hukum pidana positif saat ini, karena perbuatannya bersifat maya/ abstrak/non-fisik dan sangat individual. Walaupun dinyatakan di atas, bahwa cyber sex merupakan bentuk lain dari perzinahan atau hubungan seksual gelap/haram/melanggar hukum (illicit sexual relations), namun sulit dijaring dengan Pasal 284 KUHP kalau pengertian zinah selalu dikaitkan pada adanya "hubungan seksual (persetubuhan) secara fisik". 
Inilah salah satu kelemahan hukum pidana konvensional saat ini yang selalu bertolak dari paradigma perbuatan dalam arti fisik/materiel.

Namun sekiranya dalam praktek peradilan, khususnya dalam kasus cybersex ini, hakim akan melakukan konstruksi hukum dengan menyatakan bahwa cybersex atau "hubungan seksual non-fisik (maya)" ini merupakan bentuk zina dalam pengertian Pasal 284 KUHP, maka menurut saya konstruksi hukum demikian cukup beralasan, mengingat :

(1) Pasal 284 sendiri tidak memberikan pengertian/batasan juridis tentang apa yang dimaksud dengan zinah; dengan kata lain, Pasal 284 sama sekali tidak menyebutkan unsur-unsur zinah secara eksplisit;

(2) Adanya unsur "hubungan seksual/persetubuhan secara fisik" hanya merupakan pendapat umum dan pendapat yang berkembang dalam teori/doktrin maupun jurisprudensi;

(3) Pendapat umum/doktrin/jurisprudensi itu didasarkan pada paradigma/konsep perbuatan dalam arti materiel/ fisik, sedangkan saat ini ada perkembangan paradigmal konsep perbuatan secara fungsional dan secara keilmuan;
(4) Penafsiran yang bertolak dari paradigma fungsional dan paradigma keilmuan terhadap beberapa pengertian hukum (seperti "perbuatan", "barang", "subjek hukum", "orang") sudah dike ngkan/ digunakan dalam praktek pembuatan UU dan jurisprudensi selama ini;

(5) Beberapa kasus pencurian dalam jurisprudensi telah juga diartikan secara non-fisik, misalnya kasus pen-curian listrik (Arrest HR 23 Mei 1921) dan kasus pembobolan dana BNI 1946 New York Agency melalui komputer (dengan "transfer electronic payment system? yang dinyatakan oleh Mahkamah Agung $\mathrm{Rl}^{31}$ sebagai "pencurian" (berarti "mengambil barang secara non-fisik");

(6) Dalam sumber artikel di internet yang berjudul "Cyber Sex There are organizations out there to help you" dinyatakan, bahwa cyber sex merupakan "adultery" (zinah). Dikemukakan dalam tulisan itu, intinya sebagai berikut : "Untuk orang yang sudah menikah, melakukan aktivitas cybersex merupakan suatu bentuk perzinahan (For a

\footnotetext{
31 Putusan MA-RI No. 1882. K./Pid/1988 tgl. 21
} Desember 1988. 
married person to engage in this activity con-stitutes a form of adultery). Dilihat dari sudut hukum, hal itu merupakan wilayah kelabu, namun hal itu hanya disebabkan pengadilan tidak dapat mengejar waktu. Pengadilan dapat menetapkan cybersex itu sebagai "perzinahan" (adultery) atau sebagai bentuk "penelantaran" (abandonment). Dilihat secara moral, jelas merupakan bentuk penipuan (form of cheating), dan dari sudut agama merupakan bentuk perzinahan (form of adultery)".

(7) Dilihat dari sudut pandang agama Islam, jelas cybersex itu merupakan zinah. Hal ini dikemukakan oleh Dr. Muzammil H. Siddiqi (mantan President of the Islamic Society of North America) sewaktu menjawab pertanyaan seseorang melalui internet, "apakah cyber sex dan phone sex merupakan zina" (/s cyber sex or phone sex considered an adultery (Zina)?. la menjawab :

Cyber Sex There are organizations out there to help you" (http://www. Cyberaa.com).

${ }^{3}$ FatwaCyber Sex \& Zina, (Islamonline.net), (http://pakistanlink.com/religion/2001/0413. html).
"Zina menurut syariah adalah setiap hubungan seksual yang haram/ terla-rang. Oleh karena itu, seks sebe/um nikah, di luar nikah, dan homoseks, semuanya adalah zina. Zina merupakan dosa besar dan mutlak dilarang (haram). Islam tidak hanya melarang hubungan sek-sual yang haram, tetapi juga melarang setiap per-buatan yang mengarah/ men-dekati dosa ini. Cyber sex, phone sex dsb. Merupakan perbuatan yang dapat mengarah/mendekati zina".

(Zina according to Shari"ah is any illicit sexual intercourse. Thus pre-marital sex, extra marital sex and homosexuality are all considered Zina according to Islamic law. Zina is a major sin (Kabirah); It is absolutely forbidden. Islam does not only forbid illicit sexual intercourse, but also forbids anything that leads to this sin and crime. 'Cyber sex', 'phone sex', etc. are those activities that can lead to Zina").

Dengan uraian di atas, dapatlah disimpulkan bahwa konstruksi "cyber sex" sebagai bentuk zina, cukup beralasan dilihat dari sudut : (a) 
Juridis normatif, (b) Juridis konseptual/teoritik/keilmuan, (c) Jurisprudensi, (d) Pandangan pakar/ artikel cyber crime (cybersex), (e) Agama, dan dari sudut (f) Akibat sosial (dampak negatif)nya.

\section{Kebijakan Antisipatif Hukum Pidana Yang Akan Datang}

Sehubungan dengan kelemahan jurisdiksi di dalam KUHP dalam meng-hadapi masalah cyber crime, maka dalam Konsep RUU KUHP 2004/2005, dirumuskan perluasan asas teritorial dan perumusan delik Pornografi Anak melalui Komputer, sebagai berikut :

Asas Wilayah atau Teritorial

\section{Pasal 3}

Ketentuan pidana dalam peraturan perundang-undangan Indonesia berlaku bagi setiap orang yang melakukan:

a.tindak pidana di wilayah Negara Republik Indonesia;

b.tindak pidana dalam kapal atau pesawat udara Indonesia; atau

c. tindak pidana di bidang teknologi informasi yang akibatnya dirasakan atau terjadi di wilayah Indonesia dan dalam kapal atau pesawat udara Indonesia.
Pornografi Anak melalui Komputer Pasal 380

Dipidana dengan pidana penjara paling lama 7 (tujuh) tahun dan denda Kategori IV setiap orang yang tanpa hak melakukan tindak pidana yang berkaitan dengan pornografi anak berupa :

a. memproduksi pornografi anak dengan tujuan untuk didistribusikan melalui sistem komputer;

b. menyediakan pornografi anak melalui suatu sistem komputer;

c. mendistribusikan atau mengirimkan pornografi anak melalui sistem komputer;

d. membeli pornografi anak melalui suatu sistem komputer untuk diri sendiri atau orang lain; atau

e. memiliki pornografi anak di dalam suatu sistem komputer atau dalam suatu media penyimpanan data komputer.

Perlu dikemukakan, bahwa perumusan delik pornografi anak di atas merupakan salah satu bagian dari perumusan delik cyber crime lainnya, yang di dalam Konsep RUU KUHP dikelompokkan ke dalam "Tindak Pidana terhadap Informatika dan Telematika" (ditempatkan sebagai salah satu bagian dari Bab VIII Konsep RUU KUHP). Di samping itu, tindak pidana 
kesusilaan seperti yang ada di dalam KUHP, diperluas lagi dalam Konsep RUU KUHP 2004/2005 dengan menambahkan sub-bab khusus mengenai pornografi dan pornoaksi, yang dapat dilakukan juga melalui media massa elektronik dan/ atau alat komunikasi media.
DAFTAR PUSTAKA

Allen, Kenneth, Cyber-Sex A Review and Implications of the Situation, home.earthlink.net

Australian High Tech Crime Centre 2003

Bowker, Arthur and Michael Gray, An Introduction to the Supervision of the Cybersex Ofiender, Federal Probation's publication, Volume 68 Number 3, Published by the Adminis-trative Office of the United States Courts (Www. uscourts.gov Publishing Information)

Brame, Gloria G., "Boot Up and Tum Or'; 1996, gloria-brame. com/glory/journ 7.htm

Conner, Michael G., Internet Addiction \& Cyber Sex, (www. CrisisCounseling.org)

Council of Europe; Data Protection Working Party, Council of Europe, "Opinion 4/2001 On the Council of Europe's Draft Convention on Cyber-crime", adopted on 22 March 2001, 5001/01/EN/Final WP 41.

Cyber Sex There are organizations out there to help you" (http://www. Cyberaa.com).

Dudeja, V.D., Cyber Crimes and Law, Volume 2, 2002.

Eighth UN Congress on the Prevention of Crime and the Treatment of Offenders, Report, 1991.

Eleventh United Nations Congress on Crime Prevention and Criminal Justice, Bangkok, 18-25 April 2005, Background paper, 
Workshop 6: Measures to Combat Computer-related Crime, Dokumen United Nations A/CONF.203/14.

Fatwacyber Sex \& Zina, (Islamonline.net),

(http://pakistanlink.com/religion/2001/ 0413. html).

Goldberg, Peter David, An Exploratory Study About the Impacts that Cybersex (The Use of the Intemet for Sexual Purposes) is Having on Families and The Practices of Mamiage and Family. Therapists, 2004, (pedrogoldberg@aol.com)

Griffiths, Mark, Sex on the Intemet: obsenvations and implications for Intemet sex addiction, Journal of Sex Research, Nov 2001, mark.griffiths @ @ntu.ac.uk.

ITAC, "IIIC Common Views Paper On: Cyber Crime", IIIC 2000 Millenium Congress, September $19^{\text {th }}, 2000$.

Konsep RUU KUHP, Edisi 2005.

McLaughlin, James F., Cyber Child Sex Offender Typology, jmclaughlin@ci.keene.nh.us

Nawawi Arief, Barda, "Bunge Rampai Kebijakan Hukum Pidana", PT Citra Aditya Bakti, Bandung, 1996.

nanggulangan. "Cybor-Crime" De-
ngan Hukum Pidana, makalah
pada Seminar Nasional "Cyber
Law", STHB Bandung, Hotel
Grand Aquila, 9 April 2001.

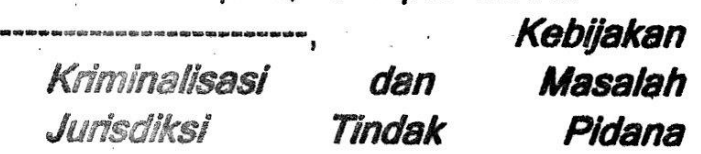

Mayantara, Seminar Nasional RUU Teknologi Informasi (CyberLaw) "Pemberdayaan Teknologi Informasi dalam Masyarakat Informasi", Kerjasama Dirjen Postel DEPHUB dengan UNDIP, Gedung Ghradhika Bhakti Praja, Semarang, 26 Juli 2001:

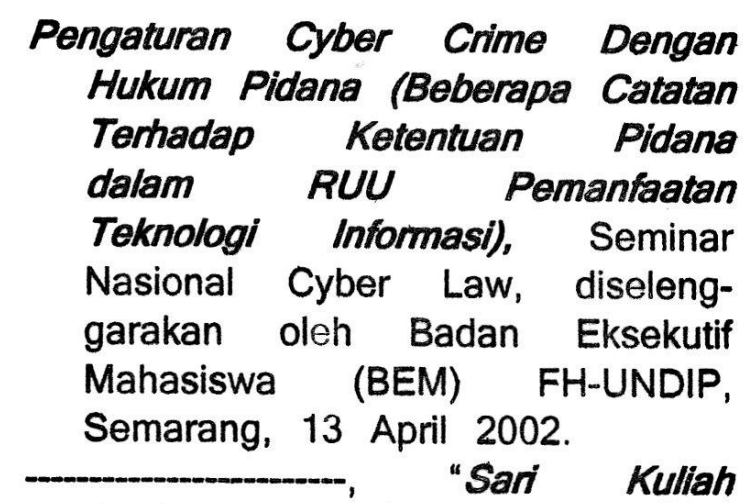

Perbandingan Hukum Pidand", PT RajaGrafindo, Jakarta, 2002.

,Kejahatan Perban-

kan Dalam Problematika Hukum Ekonomi dan Teknologi (Tinjauan Khusus Kejahatan Transfer Dana Elektronik), Seminar Nasional Problematika Perkembangan $\mathrm{Hu}$ kum Ekonomi dan Teknologi, Fakultas Hukum Universitas Muhammadiyah Yogyakarta, 29 Mei 2004. gungjawaban Pidana Cyber Crime, Seminar "Problematika Hukum Cyber Crime di Indonesia", FH UNAIR, 9 Oktober 2004.

Cyber Crimo : Pidana, Makalah pada "Seminar Nasional Tentang Cybercrime", diselenggarakan oleh Kementerian Komunikasi dan Informasi (KOM- 
INFO), di Hotel lbis Tamarin, Jakarta, 7 Desember 2004.

Possibilities of Cyber - Sex, be careful http://pw1.netcom.com/ uncleken/ cybersex.html

Senoadji, Oemar, "Mass Media dan Hukum", Erlangga, Jakarta, 1977.

Stephen Schafer, The Political Criminal, The Free Press, New York, 1973.

The California High Technology Crime Advisory Committee, Annual Report on High Technology Crime in California.

The Cyber Sex Addiction FAQ, http://www.sexualrecovery.com/sri_d ocs/cyberfaq.htm

Wikipedia, the free encyclopedia, (en.wikipedia.org/wiki/Cybersex). 